\title{
Myotoxic drugs and immunodeficiency may contribute to the poor outcome of COVID-19 patients with myotonic dystrophy
}

\author{
J. Finsterer ${ }^{1}$ iD \\ Received: 26 October 2020 / Accepted: 8 November 2020 / Published online: 23 November 2020 \\ (c) Belgian Neurological Society 2020
}

Keywords Brain $\cdot$ MRI $\cdot$ SARS-CoV-2 $\cdot$ COVID-19 $\cdot$ Encephalitis

Dear Editor,

With interest we read the article by Dhont et al. about three patients with myotonic dystrophy type 1 (MD1) who died from COVID-19 despite maximal therapy for the infection with SARS-CoV-2 [1]. It was concluded that MD1 patients are at high risk for severe COVID-19 disease with poor outcome [1]. We have the following comments and concerns.

All three patients with MD1 received chloroquine from which it is well known that it can be myotoxic [2]. Unfortunately, the authors did not provide the exact medication the three patients were receiving in addition to chloroquine [1]. From various antibiotics, including azithromycin, it is known that they can be myotoxic [3]. Azithromycin may even cause rhabdomyolysis [4]. From steroids, it is well appreciated that they may cause mitochondrial myopathy.

Patients with COVID-19 may experience critical ill neuropathy, critical myopathy, myositis, myasthenic syndrome, or myasthenia. Were there any indication for such neuromuscular disorder, which may significantly complicate the disease course in MD1 patients.

It is well known that a patient with COVID-19 can have a negative naso-pharyngeal swab test. In such cases, the PCR for the virus may be positive in other body fluids, particular the bronchial fluids [5].

From MD1 it is known that it may also affect the cellular immune system, leading to immunodeficiency and thus recurrent infectious disease. Thus, we should know if any of the three included patients had a history of recurrent infectious diseases.

J. Finsterer

fifigs1@yahoo.de

1 Klinik Landstrasse, Messerli Institute, Postfach 20,

1180 Vienna, Austria
Overall, the study by Dhont et al. could be more meaningful if all drugs the three patients were receiving during hospitalisation were provided if readers were informed if any of the three patients had rhabdomyolysis, and if any of the three had immunodeficiency as a manifestation of MD1. MD1 patients experiencing COVID-19 may be at risk of developing side effects to myotoxic medication more frequently than COVID-19 patients without an underlying neuromuscular disorder.

Author contributions JF: design, literature search, discussion, first draft, critical comments.

Funding No funding was received.

\section{Compliance with ethical standards}

Conflicts of interest The authors declare no conflicts of interest.

Ethical standards The article does not contain any studies with human participants performed by any of the authors.

Informed consent Informed consent was obtained. The study was approved by the institutional review board.

\section{References}

1. Dhont S, Callens R, Stevens D, Bauters F, De Bleecker JL, Derom E, Van Braeckel E (2020) Myotonic dystrophy type 1 as a major risk factor for severe COVID-19? Acta Neurol Belg. https://doi. org/10.1007/s13760-020-01514-Z

2. Haberl A, Fischer P, Pongratz D, Sieb JP (2005) Chloroquininduzierte. Myopathie Folge einer siebenjährigen, niedrigdosierten Basistherapie bei primär-chronischer Polyarthritis [Occurrence of chloroquine-induced myopathy after low-dose treatment of rheumatoid arthritis for seven years]. Z Rheumatol 64:274-276. https://doi.org/10.1007/s00393-005-0576-0 
3. Desnica B, Beus A, Skuhala T, Topic MB, Vickovic N, Makek N (2007) Myalgia and swelling of interphalangeal joints as sideeffect of prolonged azithromycin therapy in patient with pelvic actinomycosis: case report. Scand J Infect Dis 39:186-187. https ://doi.org/10.1080/00365540600810018

4. Strandell J, Bate A, Hägg S, Edwards IR (2009) Rhabdomyolysis a result of azithromycin and statins: an unrecognized interaction. Br J Clin Pharmacol 68:427-434. https://doi.org/10.111 1/j.1365-2125.2009.03473.x

5. Poggiali E, Vercelli A, Vadacca GB, Schiavo R, Mazzoni S, Ioannilli E, Demichele E, Magnacavallo A (2020) Negative nasopharyngeal swabs in COVID-19 pneumonia: the experience of an Italian emergengy department (Piacenza) during the first month of the Italian epidemic. Acta Biomed 91(3):e2020024. https://doi.org/10.23750/abm.v91i3.9979

Publisher's Note Springer Nature remains neutral with regard to jurisdictional claims in published maps and institutional affiliations. 